\title{
Editorial for PRAG vol 18 no 1
}

\author{
John V. Stafford ${ }^{1}$
}

Published online: 18 January 2017

(C) Springer Science+Business Media New York 2017

The tenth European Conference on Precision Agriculture took place in Tel Aviv, Israel at the Volcani Centre in July 2015. Of all the many papers presented at that conference, a number have been updated and added to with new results and analyses. Some are published in this first special issue with more to come later in volume 18. ECPA conferences come under the auspices of the International Society for Precision Agriculture. Multi-disciplinarity is a feature of Society, Conferences—and this Special Issue! Here you will find an interesting mix of papers on soils, crops, remote sensing, management and sensing techniques.

Dr Paul Carter has been my very able co-editor for the last three years but has now stepped down from the role. Editing a journal like PRAG with six issues a year is a big ask in the midst of a very full time job at Washington State University. I wish to record a very big thank you to him for his contribution to the editing work. In his place, I welcome Dr Jess Lowenberg deBoer. Jess will be known to many and has made important contributions in the development of precision agriculture.

John V. Stafford

john.stafford@silsoe-solutions.co.uk

1 Silsoe Solutions, Ampthill, Bedford, UK 